\title{
ФРОНТИРЫ:
}

УСТАРЕВШЕЕ ПОНЯТИЕ ИЛИ НОВАЯ ИССЛЕДОВАТЕЛЬСКАЯ ПЕРСПЕКТИВА?

УДК 93; ББК 63.0; DOI https://doi.org/10.21638/spbu19.2020.104

\author{
Dmitriy V.Sen'
}

\section{FRONTIER RESEARCH IN PRESENT-DAY RUSSIA: SHAKY BOUNDARIES OF THE ACADEMIC DIALOGUE}

The frontier concept is a paradox for the present-day Russian research. On the one hand it is a popular concept that has been widely used at different times with regard to almost every border of Russia, including Siberian, North Caucasian, Central Asian, Karelian, Baltic borders, etc. On the other hand, debates have not ended about the possibility of using such an approach with respect to Russian history ${ }^{1}$.

The frontier concept has often been accused of being used opportunistically. According to Yury Priimak, the frontier is a «loophole» (!), intended to «...justify the predominantly confrontational character of the Russian North Caucasus formation $»^{2}$. Oleg Matveev took an even harder view: «...in some cases 'frontier' is going to develop into a historiographic 'front'» ${ }^{3}$. Boris Vinogradov and Oleg Klochkov state that frontier theory in Russian scholarship is «historical falsification» ${ }^{4}$. In some contemporary works the 'frontier' concept is groundlessly

${ }^{1}$ The author explores the heuristic potential of the frontier theory within the framework of a state grant-the project «Comprehensive study of the processes of socio-political and cultural development of the peoples of the South of Russia» (№ AAAA-A19-119011490038-5).

${ }^{2}$ Приймак Ю. В. Северо-Восточное Причерноморье во внутри- и внешнеполитических процессах формирования южных границ России (конец XVII - первая треть XIX в.). Армавир, 2011. C. 72.

${ }^{3}$ Матвеев О. В. От фронта к фронтиру: Историко-антропологические очерки. Краснодар, 2015. C. 29.

${ }^{4}$ Виноградов Б. В., Клочков О. Б. «Северокавказский фронтир» от фонда Сороса: К вопросу о целях и характере исторической мистификации // Историческое регионоведение Северного

(C) D. V. Sen', 2020 
likened to the 'front'. For example, Elena Berberova has compared the frontier to a 'boundary line', 'frontier confrontation', and - indicatively - to intolerance, which is allegedly inherent in the frontier ${ }^{5}$. Finally, Tatyana Soboleva and Denis Bobrov have determined that the frontier approach is essentially 'antagonizing' ${ }^{6}$.

Why, in spite of all these serious objections, has the field of the frontier research in Russia continued to expand? The frontier concept has shown research 'elasticity' not only by the example of the wide - essentially, world-wide — range of territories with an 'unstable equilibrium', the mosaic structure of social and cultural processes, the 'informality' of local life, the entropy of official authority relations, and public resources for the purpose of coercion and control. Such parallels are especially interesting in connection with the simultaneous use of the heuristic potential of the given theory and 'new imperial history', which actively deconstructs the traditional imperial narrative and suggests unconventional explanations of the so-called 'imperial situation'? In this case, new aspects of the imperial historical phenomenon are the object under study: «Our starting point is not the historical structure of political, social and cultural differences, but rather the moment when these differences are signified and semiotically marked $\iota^{8}$. The appearance of new identities and new 'social statuses' in the frontier space, life in the borderland, which cannot be in every way controllable by the imperial authorities, multiple reactions of the heterogeneous frontier population to the actions of the authorities in the 'nobody's' frontier space - these and other features bring to light the phenomenon of a «...complex heterogeneous community out of the shadow of historical empires and influential nationalistic propaganda of one-dimensionality and purity $\rangle^{9}$. Dmitry Zamyatin likened such movable boundaries to an 'amalgam' that strongly 'pulls together' diverse and distant places ${ }^{10}$.

The frontier is characterized by cultural mosaicity, uncertainty («unstable equilibrium», according to Nadezhda Zamyatina ${ }^{11}$ ), and the lack of clear state demarcation of territory, so that there is no predetermined orientation of local life processes and events. It appears possible to suggest the multiplicity of historical actors in the frontier space, the concept of which

Кавказа - вузу и школе: Материалы научно-педагогического семинара. М.; Армавир, 2008. C. 29-33.

${ }_{5}^{5}$ Берберова Е. Г. Особенности северокавказского фронтира Российской империи (1722-1864 гг.): Автореф. дис. ... канд. ист. наук. Владикавказ, 2014. С. 13, 18, 20. — See also: Шебзухова T. А., Берберова Е. Г. Северокавказский фронтир Российской империи (1722-1864). М., 2015.

${ }^{6}$ Соболева Т. Н., Бобров Д. С. Современная российская историография концепции фронтира // Известия Алтайского государственного университета. 2011. № 4-1. С. 192.

${ }^{7}$ Герасимов И. В., Глебов С. В., Каплуновский А. П., Могильнер М. Б., Семенов А. М. В поисках новой имперской истории // Новая имперская история постсоветского пространства. Казань, 2004. С. 7-29.

${ }^{8}$ Герасимов И. В., Глебов С. В., Кусбер Я., Могильнер М. Б., Семенов А. М. Новая имперская история и вызовы империи // Ab Imperio. 2010. № 1. С. 20.

${ }^{9}$ Новая имперская история Северной Евразии. Ч. 1: Конкурирующие проекты самоорганизации: VII-XVII вв. / Под ред. И. В. Герасимова. Казань, 2017. С. 10.

10 Замятин Д. Н. Русские в Центральной Азии во второй половине XIX века: Стратегии репрезентации и интерпретации историко-географических образов границ // Восток. Афроазиатские общества: История и современность. М., 2002. № 1. С. 44.

11 Замятина Н. Ю. Зона освоения (фронтир) и ее образ в американской и русской культурах // Общественные науки и современность. 1998. № 2. С. 82. 
is in great demand today, in order «to incorporate ... the ambiguous porosity of the border into our understanding of the ways in which human beings tend to divide and separate social space $\rangle^{12}$. Those are such people as law-breakers, spies, metis (tuma), slaves and slave-owners, merchants, diplomats and many others, whose individual and collective biographies have not always been in the focus of both colonial and postcolonial research.

«Ab Imperio» editors suggest that noteworthy idea that the concepts of the frontier, border, or transitional zone are connected with the opposition to the prevailing metanarratives inherent in the research of nationalism and empire ${ }^{13}$. The frontier concept, combined with other similar theories and explanatory constructions, essentially shifts the research focus from describing large social units and identities, to individuals' attitudes to these identities and the description of differences that cannot be reduced to inverse attraction of the frontier 'periphery' to its historical/cultural 'nucleus'.

We agree with Brian Boeck, who noted that the task of the new generation of frontier researchers is not to exclude any historical actors from the concept of the past, but rather to include groups (women, children, metis, natives, outcasts, minorities, the oppressed) and features (cultural interaction, human-nature relationship, common law, crime, relationship between the strong and the weak, identities and mentalities) that went unnoticed previously ${ }^{14}$. In their study of the problems in question, scholars may benefit from the conclusion reached by Igor Kopytoff: The frontiers are peculiar 'incubators' for the organization and development of new societies, since there is no possibility or desire to repeat in every detail the forms of the centre social life ${ }^{15}$.

From this, several important research perspectives arise: the porosity (penetrability) of boundary lines may apply not only to actual geography, but also to symbolic geography, including the area of the 'imaginary' geographic space and the cultural notions of the frontier population. Rather than focus on state borders, which, as a rule, are valued as a progressive tool in struggling the steppe and the 'predation' of the so-called underdeveloped nomads and similar communities, we can now concentrate on rather extensive transitional zones with interacting different cultural and political influences and traditions ${ }^{16}$.

Perhaps the most important thing that may happen in the field of frontier studies is the essential deconstruction of the imperial and the present-day national historical narratives of so-called 'local' or 'regional' history ${ }^{17}$, which is often and unreasonably rigidly legitimated (in polar estimates and characteristics) along the lines of 'conquest/resistance', 'progress/ traditionalism', or 'newcomers/indigenous people'. The frontier concept contributes to the

${ }_{12}$ Рибер А. Меняющиеся концепции и конструкции фронтира: Сравнительно-исторический подход // Новая имперская история постсоветского пространства: Сборник статей. Казань, 2004. С. 199.

${ }^{13}$ Границы империи: В поисках пределов применимости исторических метанарративов // Ab Imperio. 2003. № 1. С. 9-10.

${ }^{14}$ Боук Б. Фронтир или пограничье? Роль зыбких границ в истории донского казачества // Социальная организация и обычное право: Материалы науч. конф. Краснодар, 2001. С. 150.

${ }^{15}$ Kopytoff I. The African Frontier: the Reproduction of Traditional African Societies. Bloomington, 1987. P. 14.

${ }^{16}$ Миллер А. И. Ментальные карты историка и связанные с этим опасности // Исторические записки. М., 2002. Вып. 5 (123). С. 328.

${ }^{17}$ Репина Л. Между локальным и глобальным: Поиски интегративных подходов // Регіональна історія України: Збірник наукових статей. Київ: 2011. Вип. 5. С. 10. 
conceptualization of new regional historical studies required for the understanding of processes that went beyond state and national borders.

The reason why Russian scholars adopted the frontier concept in the late $20^{\text {th }}-$ early $21^{\text {st }}$ century was not only «... searching for an alternative to the traditional narrative of colonization and overcoming the ideologically caused ideas of the steppe borderland as the 'front line'», as Vladislav Gribovsky puts $i^{18}{ }^{18}$. In our opinion, this problem should be looked at in a wider context. First, at that time a considerable renewal of the theoretical toolkit for historical studies in Russia began, among other things due to the active use of numerous 'western' concepts and theories: imperial discourse, imaginary geography, orientalism, etc. We agree with Irina Basalaeva's remark that «the frontier concept is estimated as the 'growth area' of the postSoviet social and historical knowledge $\rangle^{19}$. Second, a considerable positive role was played by the study of the imperial systems and imperial experience of governing remote areas of Russia, the history of forming the borders and transforming the borderlands of the Russian state, which is today a noticeable area in the Russian historiography. Third, already in the 1990s, new areas of historic studies were actively taking shape in Russia against the unstable background of post-Soviet historical scholarship, rid of ideological bias. All that occurred along with the flourishing of the so-called regional historical approach and regional historical narratives ${ }^{20}$, including narratives that deconstructed previous versions of the Russian empire's national policy. Fourth, publications by several authoritative foreign researchers produced a beneficial effect on the development of the frontier studies, especially in the South of Russia ${ }^{21}$. Discussions continue in Russia on the heuristic potentials of frontier theory and the theory of contact zones $^{22}$. In our opinion, the analytical capabilities of the latter are inferior to those of frontier theory, as they simplify the interaction between the Russian and the Caucasian worlds,

${ }^{18}$ Грибовский $B$. В. Казачество и его связь с тюркским миром в историографии поздней Российской империи, СССР и постсоветского пространства // Казачество в тюркском и славянском мирах: Коллективная монография / Отв. ред. Грибовский В. В., Трепавлов В. В. Казань, 2018. С. 55.

${ }^{19}$ Басалаева И. П. Критерии фронтира: К постановке проблемы // Теория и практика общественного развития. 2012. № 2. С. 46.

${ }^{20}$ Миллер А. И. Империя Романовых и национализм: Эссе по методологии исторического исследования. М., 2006. С. 14-32.

${ }^{21}$ Каппелер A. Южный и восточный фронтир России в XVI-XVIII веках // Ab Imperio. 2003. № 1. С. 47-64; Баррет T. М. Линии неопределенности: Северокавказский «фронтир» России // Американская русистика: Вехи историографии последних лет. Императорский период: Антология / Сост. М. Дэвид-Фокс. Самара, 2000. С. 163-193; Barret T. M. At the Edge of Empire. The Terek Cossacks and the North Caucasus Frontier, 1700-1860. Boulder, 1999. 22 Гатагова Л. С. Контактные зоны в истории Восточной Европы. М., 1998; Олейников Д. И. 1) Теория контактных зон и диалога культур применительно к продвижению России на Северный Кавказ в 1810-1860-е гг. // Actio nova. M., 2000. С. 315-337; 2) Человек на разломе культур. Особенности психологии русского офицера-горца в период Большой Кавказской войны // Звезда. 2001. № 8. С. 95-99; Черноус В. В. Культурно-цивилизационное взаимодействие на Северном Кавказе: История и некоторые современные тенденции // История: Научные поиски и проблемы. Ростов-на-Дону, 2000. С. 164-187; Хльнина Т. П., Кринко Е. Ф., Урушадзе A. T. Российский Северный Кавказ: Исторический опыт управления и формирования границ региона. Ростов-на-Дону, 2012. С. 8-9; Матвеев О. В. От фронта к фронтиру... C. 29-30. 
as if gradually turning the civilizational fracture into a healing stitch. Noteworthy, Amiran Urushadze states that Russian scholars' active adoption of modern theoretical insights into frontier problems made the further development of the 'contact zone' theory 'unreasonable' in Russia ${ }^{23}$.

Brian Boeck observed that «much as we would like to avoid foreign 'jargon' we cannot find an equivalent to the term 'frontier' in the modern Russian language ${ }^{24}$. Nevertheless, Russian and Ukrainian historiographies are looking for the lexical counterpart to 'frontier' 25 . Some specialists are trying to find a counterpart to 'frontier' in historical and geographical lexicon, e.

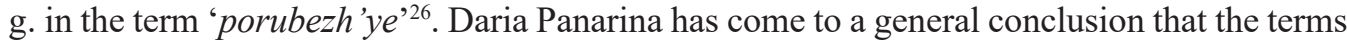
'porubezh'ye' and 'frontier' are semantically inconsistent. "The comparison of the Russian terms 'rubezh' (border) and 'porubezh'ye' (borderland) with the American 'frontier' shows that neither of the suggested Russian terms has the same contextual content as the American one: neither rubezh nor porubezh'je are initially defined as zones where peoples and cultures clash or interact. To an even lesser extent, rubezh can be described as the territory where new communities, nations, or states are formed, like at the American frontier. Therefore, the concept of rubezh is insufficient ${ }^{27}$. Yury Mizis, Oleg Skobelkin, Andrey Papkov write almost the same about terminology problems concerning the southern Russian frontier ${ }^{28}$. Thus, in the opinion of many scholars (including the author of this paper), no succinct counterpart to 'frontier' has been found in the Russian language that would possess similar operational capabilities for describing the same historical situation (when typologically compared to the American frontier).

Other Russian scholars deny that the heuristic potential of the 'frontier' can be verified with respect to the Russian historical material. These specialists feel more comfortable to proceed from Turner's understanding of the frontier. However, today this does not prevail in research of 'frontier discourse' or borderlands history. Now there is no need to revert to Turner's thesis of the frontier as the meeting point between 'savagery and civilization'. Critics of the frontier concept wrongly equate the Turner Thesis with a Frontier Thesis, marginalizing this area in the humanities for no good reason.

In Russian academic community it is still widely believed that Frederick Jackson Turner's concept was similar to scholarly views of Sergey Solov'ev and Vasily Klyuchevsky. As Mark Bassin has shown, Turner's definition of 'frontier' has common features with the definition

${ }^{23}$ Хльлнина Т. П., Кринко Е. Ф., Урушадзе А. Т. Российский Северный Кавказ... С. 9.

${ }^{24}$ Боук Б. Фронтир или пограничье? С. 147.

${ }_{25}^{25}$ Панарина Д. С. Граница и фронтир как фактор развития региона и/или страны // История и современность. 2015. № 1 (март). С. 15-41; Чорновол I. Відповідники поняття frontier у інших мовах // Historia-Mentalność-Tożsamość. Rosja i Europa Zachodnia w polskiej i ukraińskiej historiografii XIX i XX wieku / Pod red. E. Koko, M. Nowak, L. Zaszkilniak. Gdańsk, 2013. S. $125-140$.

26 Замятина Н. Ю. Зона освоения (фронтир) и ее образ в американской и русской культурах // Общественные науки и современность. 1998. № 2. С. 77; Кравченко В. Харьков / Харків: Столица пограничья. Вильнюс, 2010. С. 25.

${ }^{27}$ Панарина Д. С. Граница и фронтир... С. 24-25.

${ }^{28}$ Мизис Ю. А., Скобелкин О. В., Папков А. И. Русский фронтир: Политические, социальные и экономические аспекты: (Юг России в XVI - конец XVIII в.) // Вестник Тамбовского государственного университета. 2015. Т. 20. Вып. 10. С. 7-15. 
of the place, role, and meaning of colonization in Russian history, according to Solovyev ${ }^{29}$. According to Klyuchevsky, colonization is the process of developing and settling new territories $^{30}$. However, no less (even more) significant is the different direction of both concepts. For example, Solovyev has not developed his thesis of the colonization role with respect to the modern history of the Russian state. For Klyuchevsky, the colonization area in Russia expanded exclusively 'together with its state territory (italics ours. - D. S.) $)^{31}$. This historiographic case may not have concerned the social history of those who developed new lands, even by 'free colonization'. Besides, as Alfred Rieber correctly observed, Solovyev's and Klyuchevsky's interpretations of colonization processes, as distinct from the Turner thesis, underlined the negative aspects of the border phenomenon in the history of Russia: depletion of resources from the center, the threat of nomadic attacks, etc. ${ }^{32}$ Most importantly, «Turner focused his attention ... on the western frontier's own culture, elaborately studying how it influenced the culture of the eastern states $\rangle^{33}$. Based on sometimes unreasoned convergence of the American frontier and the Russian colonization, a hasty and unconvincing conclusion is made that «the modern 'frontier' theory is essentially an alternative to the 'colonization' theory» ${ }^{34}$.

Noteworthy, the adoption of the frontier concept by the Russian academic and research field in the 1990s occurred at the time of another wave of criticism of Turner's concept by supporters of 'new western history'. Patricia Nelson Limerick, professor of history in the Colorado University (USA) and a prominent representative of the modern discussion, called for the rejection of the criticized notion due to its allegedly expansionist ring and its role in fixing all possible colonial stereotypes that form the heavy burden of 'the conquest legacy ${ }^{35}$. She characterized the term 'frontier' as nationalistic, racist, and ethnocentric ${ }^{36}$, suggesting the equation of the terms 'border' and 'conquest'. The frontier theory was no less objected to in the works of Limerick's active supporters Richard Slotkin and David Murdoch, who critically analysed the main cultural myths about the American frontier ${ }^{37}$. At the same time, research is still being carried out in present-day worldwide scholarship on the history

${ }^{29}$ Bassin M. Turner, Solovyev, and the «Frontier Hypothesis»: The Nationalist Signification of Open Spaces // The Journal of Modern History. 1993. Vol. 65. № 3 (Sept.). P. 473-511.

${ }^{30}$ Ключевский В. О. Сочинения: В 9 т. Т. 1. М., 1987. С. 50-53.

${ }^{31}$ Ключевский В. О. Сочинения. Т. 1. С. 49-51.

32 Рибер А. Меняющиеся концепции и конструкции фронтира... С. 199-222.

33 Эткинд А. М. Внутренняя колонизация: Имперский опыт России. М., 2013. С. 94. — On the contradictions of Solovyev's concept of colonization, see: Ibid. C. 92-93.

${ }^{34}$ Голованова С. А., Шнайдер В. Г. Концепция «фронтира» в современной кавказоведческой литературе // Вестник Адыгейского государственного университета. Сер. 1: Регионоведение: философия, история, социология, юриспруденция, политология, культурология. 2012. Вып. 3. C. 66-74. URL: https://cyberleninka.ru/article/n/kontseptsiya-frontira-v-sovremennoykavkazovedcheskoy-literature (дата посещения - 20.08.2018).

${ }_{35}$ Limerick $P$. The Legacy of Conquest. The unbroken past of the American West. New York, 1987. - See also: Nash G. Creating the West: Historical Interpretations 1890-1990. Albuquerque, 1991; Worster D. Under Western Skies: Nature and History in the American West. New York, 1992. ${ }^{36}$ Limerick $P$. «What on Earth is the New Western History?»/ Trails: toward a new western history / Ed. by P. Limerick, C. Milner II, C. Rankin. Kansas, 1991. P. 85.

${ }^{37}$ Slotkin R. 1) Regeneration through violence: The mythology of the American frontier, 1600 1860. Norman, 2000; 2) The fatal environment: the myth of the frontier in the age industrialization, 
of frontier territories, the frontiers in the global comparative historical perspective, and in the Russian perspective ${ }^{38}$.

In conclusion it should be stated that for over 25 years, Russian historiography has accumulated experience in order to find in Russian concrete historical material the new grounds for further use of the frontier concept for the benefit of global academic scholarship. Today, research is being carried out in Russia on the history of several Russian frontiers, such as the 'eastern' (related to the Far East), 'donskoi' (along the Don), 'zakubanskiy' (behind the Kuban River), 'povolzhskiy' (along the Volga). Yet, the historiographic situation in the early 2000s looked different. Regional, above all, university-level academic communities can play a special role in realizing new 'frontier discussions' on a national scale, as they have a priority in studying Russian frontiers. Scholars and research teams from Belgorod, Vladivostok, Voronezh, Krasnodar, Krasnoyarsk, Novosibirsk, Rostov-on-Don, Tambov, Tomsk, and other cities have consistently performed such studies. We face a historiographic situation which is not quite typical for the Russian scholarship, when representatives of regional academic communities, rather than the members of 'the big' Russian Academy, can shape the nationwide academic discussion.

The prospects for frontier theory may go beyond the study of the history of the Russian borderlands. First, the frontier concept is more and more widely used to understand not only likenesses but also differences inherent in peoples and phenomena within frontier territories, e. g. in Siberia ${ }^{39}$. Second, there are methodological restrictions for the comparative study of the American frontier and various 'Russian frontiers', first of all the 'Siberian' and the 'Caucasian' ('southern Russian'). In this connection, the anxiety of certain authors who expressed their version of 'dangers' supposedly hidden in the frontier theory seems somewhat belated ${ }^{40}$. The modern Ukrainian author is right when he notes that «one should not expect frontier studies to explain why the democracy in Zaporozhye and the Don region was not based on the codified law as in the USA but rather on a flexible custom, which eludes codification ${ }^{41}$. Third, the consistent classification of Russian frontiers has been developed mainly through efforts by experts from academic centers in Siberia. In some cases, Russian scholars' academic pursuits took the line of a search for additional terminology. For example, one group of Russian scholars in the mid-2000s

1800-1890. Norman, 1998; 3) Gunfighter nation: the myth of the frontier in twentieth-century America. Norman, 1998.

${ }^{38}$ Hall D. T. Puzzles in the Comparative Study of Frontiers: Problems, Some Solutions, and Methodological Implications // Journal of World-Systems Research. 2009. Vol. XV. № 1. P. 25-47; White R. Middle Ground: Indians, Empire, and Republics in the Great Lakes Region. 1650-1815. New York, 1991; Dislocating the Frontier: Essaying the mystique of the Outback / Rose D. B., Davis R. (eds). Canberra, 2005; Frontiers in Question. Eurasian Borderlands. 700-1700 / Ed. by D. Power, N. L. Standen. New York, 1999; Khodarkovsky M. Russia's Steppe Frontier: The Making of a Colonial Empire, 1500-1800. Bloomington; Indianapolis, 2002; Sunderland $W$. Taming the wild field: Colonization and Empire on the Russian Steppe. Ithaca; London, 2004.

${ }^{39} X p$ ромых A. C. К вопросу о применении понятий «колонизация» и «фронтир» в изучении истории Сибири // Исторические исследования в Сибири: Проблемы и перспективы. 2009. C. 113 .

${ }^{40}$ Северный Кавказ в составе Российской империи. М., 2007. С. 56.

${ }^{41}$ Грибовский В. В. Казачество и его связь с тюркским миром... С. 59. 
introduced the notion of "frontier regions" 42 to explain the inner tension inherent in the frontier conditions.

The joint effort of experts concerned is required for solving several important research issues, including the following:

- working out the chronology of the 'opening' and 'closing' of the Russian frontiers due to the evolution of the borders of Russia and other states, and establishing linear borders as the key factor that changed the configuration of frontiers and destroyed them;

- defining more precisely the typology, geography (localization), and names of Russian frontiers based on the existing models and generalization attempts suggested, for example, by Andreas Kappeler with regard to the southern and eastern frontiers of Russia;

- in the medium term, organizing and realizing new comparative studies of the South Russian and North Caucasian frontiers, or, alternatively, the North-Caucasian and Siberian frontiers as the most noticeable in the Russian history;

- organizing comparative studies of the history of frontier territories that existed simultaneously in the interimperial context, for example, of Russia and the Ottoman Empire. The history of the Don and North Caucasian frontiers is a promising area for such research cases;

- finding and analysing new sources that would allow us to widen our knowledge about the attitude of contemporaries to moving from the 'developed' into 'undeveloped' areas and vice versa; to marking those territories and areas; to violating boundaries, borderlines, borders or frontiers. To do this, one will have to turn to symbolic geography and involve the categories and terms of culture that was traditional at the time of existence of the described frontier space.

Similarly to Pekka Hämäläinen and Samuel Truett's statement about the open-ended horizons of borderlands history ${ }^{43}$, we believe that the frontier concept is still able to produce new research that has so far escaped the attention of the most consistent supporters of this theory, who look beyond the 'lines of uncertainty'...

\section{Информация о статье}

Статья подготовлена при поддержке программы развития научных журналов в рамках государственного контракта № 14.597.11.0035, заключенного между Минобрнауки РФ и НП «НЭИКОН».

Автор: Сень, Дмитрий Владимирович - доктор исторических наук, профессор, Институт истории и международных отношений, Южный федеральный университет, Ростов-на-Дону, Россия; ведущий научный сотрудник, Калмыцкий научный центр PAH, Элиста, Россия, e-mail: dsen1974@mail.ru, OrcID 0000-0002-5222-4685, Scopus ID 57211031437

Заголовок: Frontier research in present-day Russia: Shaky boundaries of the academic dialogue [Фронтирные исследования в современной России: Зыбкие границы академического диалога]

Резюме: В статье анализируется современный опыт использования концепта “фронтир” российскими учеными. Он применяется при изучении границ, пограничья, контактных зон, истории освоения Россией новых территорий. Выделены следующие дискуссионные направления: признаки фронтирных территорий, типология российских фронтиров, поиски аналогов понятию «фронтир» в русском языке и в номенклатуре русских историко-географических названий. Автор отмечает случаи отрицания в историографии эвристического потенциала концепта фронтира применительно к российской истории. Проанализирована система аргументов “за" и “против” применения этого понятия. Проблемы и перспективы фронтирной теории рассмотрены в сравнении с украинской и американской историографией. Современные ученые из разных стран стараются найти лексические аналоги понятию

${ }^{42}$ Алексеев В. В., Алексеева Е. В., Зубков К. И., Побережников И. В. Азиатская Россия в геополитической и цивилизационной динамике. XVI-XX века. М., 2004. С. 208.

${ }^{43}$ Hämäläinen P., Truett S. On Borderlands // The Journal of American History. 2011. Vol. 98. № 2 (September). P. 338. 
«фронтир» в целях объяснения историко-культурной специфики различных территорий. При этом ряд историков предлагает отказаться от данного понятия в исследовательских практиках. Внимание обращается на причины активного использования теории фронтира представителями региональных научных центров России. В статье также рассмотрены общие и отличительные черты в исследованиях по истории российских фронтиров, среди которых наиболее заметное место принадлежит сибирскому и южному (северокавказскому) фронтирам. Наблюдается связь между некоторыми тенденциями развития фронтирных исследований в России и всплеском интереса к региональной истории, истории формирования и расширения границ Российского государства и его внешней политики. Автор обращает внимание на цикл работ нового поколения, появившихся под влиянием теории фронтира и существенно изменивших состояние академического гуманитарного сообщества на юге России, достаточно консервативного по отношению к современным научным концепциям. Наконец, предложены наиболее перспективные, с точки зрения автора, темы для дальнейшего использования концепта фронтира в исследованиях по истории России.

Ключевые слова: фронтир, фронтирная теория, границы, рубеж, порубежье, дискуссия, классификация, российская историография, компаративные исследования, контактные зоны

\section{Литература, использованная в статье:}

Алексеев, Вениамин Васильевич; Алексеева, Елена Вениаминовна; Зубков, Константин Иванович; Побережников, Игорь Васильевич. Азиатская Россия в геополитической и цивилизационной динамике. XVI-XX века. Москва: Наука, 2004. 600 с.

Баррет, Томас M. Линии неопределенности: северокавказский «фронтир» России // Американская русистика: Вехи историографии последних лет. Императорский период: Антология / Сост. Майкл Дэвид-Фокс. Самара: Изд-во «Самарский университет», 2000. С. 163-193.

Басалаева, Ирина Петровна. Критерии фронтира: К постановке проблемы // Теория и практика общественного развития. 2012. № 2. С. 46-49.

Берберова, Елена Георгиевна. Особенности северокавказского фронтира Российской империи (17221864 гг.): Автореф. дис. ... канд. ист. наук. Владикавказ, 2014. 22 с.

Боук, Брайан. Фронтир или пограничье? Роль зыбких границ в истории донского казачества // Социальная организация и обычное право: Материалы научной конференции. Краснодар: РИЦ «Вольные мастера», 2001. С. 147-155.

Виноградов, Борис Витальевич; Клочков, Олег Борисович. «Северокавказский фронтир» от фонда Сороса: К вопросу о целях и характере исторической мистификации // Историческое регионоведение Северного Кавказа - вузу и школе. Материалы научно-педагогического семинара. Москва; Армавир: АГПИ, 2008. С. 29-33.

Гатагова, Людмила Султановна. Контактные зоны в истории Восточной Европы. Москва, 1998.182 с. Герасимов, Илья Владимирович; Глебов, Сергей Владимирович; Каплуновский, Александр Петрович; Могильнер, Марина Борисовна; Семенов, Александр Михайлович. В поисках новой имперской истории // Новая имперская история постсоветского пространства. Казань: Центр исследований национализма и империи, 2004. С. 7-29.

Герасимов, Илья Владимирович; Глебов, Сергей Владимирович; Кусбер, Ян; Могильнер, Марина Борисовна; Семенов, Александр Михайлович. Новая имперская история и вызовы империи // Ab Imperio. 2010. № 1. C. 19-51.

Голованова, Светлана Александровна; Шнайдер, Владимир Геннадьевич. Концепция «фронтира»в современной кавказоведческой литературе // Вестник Адыгейского государственного университета. Cep. 1: Регионоведение: философия, история, социология, юриспруденция, политология, культурология. 2012. Вып. 3. С. 66-74. (URL: https://cyberleninka.ru/article/n/kontseptsiya-frontira-vsovremennoy-kavkazovedcheskoy-literature (дата посещения - 20.08.2018)).

Границы империи: в поисках пределов применимости исторических метанарративов: От редакции // Ab imperio. 2003. № 1. С. 9-23.

Границы и пограничье в южнороссийской истории: Материалы Всероссийской научной конференции (г. Ростов-на-Дону, 26-27 сентября 2014 г.). Ростов-на-Дону: Изд-во Южного федерального университета, 2014. $628 \mathrm{c}$.

Грибовский, Владислав Владимирович. Казачество и его связь с тюркским миром в историографии поздней Российской империи, СССР и постсоветского пространства // Казачество в тюркском и славянском мирах / Отв. ред. Грибовский, Владислав Владимирович; Трепавлов, Вадим Винцерович. Казань: Институт археологии им. А. Х. Халикова АН РТ, 2018. С. 11-69. 
Замятин, Дмитрий Николаевич. Русские в Центральной Азии во второй половине XIX века: стратегии репрезентации и интерпретации историко-географических образов границ // Восток. Афро-азиатские общества: история и современность. Москва, 2002. № 1. С. 43-64.

Замятина, Надежда Юрьевна. Зона освоения (фронтир) и ее образ в американской и русской культурах // Общественные науки и современность. 1998. № 2. С. 75-88.

Kannелер, Андреас. Южный и восточный фронтир России в XVI-XVIII веках // Ab Imperio. 2003. № 1. C. 47-64.

Кравченко, Володимир. Харьков / Харків: Столица пограничья. Вильнюс: Европейский гуманитарный университет, 2010.357 с.

Матвеев, Олег Владимирович. От фронта к фронтиру: Историко-антропологические очерки. Краснодар: Эдви, 2015. 272 с.

Мизис, Юрий Александрович; Скобелкин, Олег Владимирович; Папков, Андрей Игоревич. Русский фронтир: Политические, социальные и экономические аспекты. (Юг России в XVI - конец XVIII в.) // Вестник Тамбовского государственного университета. 2015. Т. 20. Вып. 10. С. 7-15.

Миллер, Алексей Ильич. Ментальные карты историка и связанные с этим опасности // Исторические записки. Москва, 2002. Вып. 5 (123). С. 323-333.

Миллер, Алексей Ильич. Империя Романовых и национализм: Эссе по методологии исторического исследования. Москва: Новое литературное обозрение, 2006. 248 с.

Новая имперская история Северной Евразии. Ч. 1: Конкурирующие проекты самоорганизации: VIIXVII вв. / Под ред. Герасимова, Ильи Владимировича. Казань: «Аb Imperio», 2017. 364 с.

Олейников Д. И. Теория контактных зон и диалога культур применительно к продвижению России на Северный Кавказ в 1810-1860-е гг. // Actio nova. Москва, 2000. С. 315-337.

Олейников, Дмитрий Иванович. Человек на разломе культур: Особенности психологии русского офицера-горца в период Большой Кавказской войны // Звезда. 2001. № 8. С. 95-99.

Панарина, Дарья Сергеевна. Граница и фронтир как фактор развития региона и/или страны // История и современность. 2015. № 1 (март). С. 15-41.

Приймак, Юрий Владимирович. Северо-Восточное Причерноморье во внутри- и внешнеполитических процессах формирования южных границ России (конец XVII - первая треть XIX в.). Армавир: Полипринт, 2011. 359 с.

Репина, Лорина. Между локальным и глобальным: Поиски интегративных подходов // Регіональна історія України: Збірник наукових статей. Київ: Інститут історії України НАН України, 2011. Вип. 5. C. 9-28.

Рибер, Альфред. Меняющиеся концепции и конструкции фронтира: Сравнительно-исторический подход // Новая имперская история постсоветского пространства: Сборник статей. Казань: Центр исследований национализма и империи, 2004. С. 199-222.

Соболева, Татьяна Николаевна; Бобров, Денис Сергеевич. Современная российская историография концепции фронтира // Известия Алтайского государственного университета. 2011. № 4-1. С. 189-193. Урушадзе, Амиран Тариелович. Российский Северный Кавказ: Исторический опыт управления и формирования границ региона. Ростов-на-Дону: Южный федеральный университет, 2012. 280 с.

Хльнина, Татьяна Павловна; Кринко, Евгений Федорович; Урушадзе, Амиран Тариелович. Российский Северный Кавказ: Исторический опыт управления и формирования границ региона. Ростов-на-Дону: Изд-во ЮНЦ РАН, 2012. 272 с.

Северный Кавказ в составе Российской империи. Москва: Новое литературное обозрение, 2007. 460 c. Хромых, Александр Станиславович. К вопросу о применении понятий «колонизация» и «фронтир» в изучении истории Сибири // Исторические исследования в Сибири: Проблемы и перспективы. 2009. C. $108-113$.

Черноус, Виктор Владимирович. Культурно-цивилизационное взаимодействие на Северном Кавказе: история и некоторые современные тенденции // История: Научные поиски и проблемы. Ростов-наДону: Изд-во Северо-Кавказского научного центра высшей школы (СКНЦ ВШ), 2000. С. 164-187.

Чорновол, Ігор. Відповідники поняття frontier у інших мовах // Historia-Mentalność-Tożsamość. Rosja i Europa Zachodnia w polskiej i ukraińskiej historiografii XIX i XX wieku. Pod red. Eugeniusza Koko, Magdaleny Nowak i Leonida Zaszkilniaka. Gdańsk: Wydawnictwo Uniwersytetu Gdańskiego, 2013. S. $125-140$.

Шебзухова, Татьяна Александровна; Берберова, Елена Георгиевна. Северокавказский фронтир Российской империи (1722-1864). Москва: ООО «ЦИУМиНЛ», 2015. 224 с. 
Эткинд, Александр Маркович. Внутренняя колонизация. Имперский опыт России / Авториз. пер. с англ. В. Макарова. Москва: Новое литературное обозрение, 2013. 448 с.

Barret, Thomas M. At the Edge of Empire. The Terek Cossacks and the North Caucasus Frontier, 1700-1860. Boulder, CO: Westview Press, 1999. XV + 243p.

Bassin, Mark. Turner, Solovyev, and the «Frontier Hypothesis»: The Nationalist Signification of Open Spaces // The Journal of Modern History. 1993. Vol. 65. № 3 (Sept.). P. 473-511.

Dislocating the Frontier: Essaying the mystique of the Outback / Rose, Deborah Bird; Davis, Richard (eds). Canberra: ANU E Press, 2005. 206 p.

Frontiers in Question. Eurasian Borderlands. 700-1700 / Ed. by Power, Daniel; Standen, Naomi. New York: St. Martin's Press, 1999. 293 p.

Hall, Thomas D. Puzzles in the Comparative Study of Frontiers: Problems, Some Solutions, and Methodological Implications // Journal of World-Systems Research. 2009. Vol. XV. № 1. P. 25-47.

Hämäläinen, Pekka; Truett, Samuel. On Borderlands // The Journal of American History. 2011. Vol. 98. № 2 (September). P. 338-361.

Khodarkovsky, Michael. Russia's Steppe Frontier: The Making of a Colonial Empire, 1500-1800. Bloomington; Indianapolis: Indiana University Press, 2002. 304 p.

Kopytoff, Igor. The African Frontier: the Reproduction of Traditional African Societies. Bloomington: Indiana University Press, 1987. 288 p.

Limerick, Patricia Nelson. The Legacy of Conquest. The unbroken past of the American West. New York: W. W. Norton, 1987.396 p.

Limerick, Patricia Nelson. 'What on Earth is the New Western History?' // Trails: toward a new western history / Ed. by Limerick, Patricia Nelson; Milner II, Clyde A.; Rankin, Charles E. Kansas. Lawrence: University of Kansas Press, 1991. P. 81-88.

Nash, Gerald D. Creating the West: Historical Interpretations 1890-1990. Albuquerque: University of New Mexico Press, 1991. 318 p.

Slotkin, Richard. Regeneration through violence: the mythology of the American frontier, 1600-1860. Norman: University of Oklahoma Press, 2000. 670 p.

Slotkin, Richard. The fatal environment: the myth of the frontier in the age industrialization, 1800-1890.

Norman: University of Oklahoma Press, 1998. 636 p.

Slotkin, Richard. Gunfighter nation: the myth of the frontier in twentieth-century America. Norman: University of Oklahoma Press, 1998. 864 p.

Sunderland, Willard. Taming the wild field: colonization and Empire on the Russian Steppe. Ithaca; London: Cornell University Press, 2004. XVII + 239 p.

White, Richard. Middle Ground: Indians, Empire, and Republics in the Great Lakes Region. 1650-1815. New York: Cambridge University Press, 1991. XVI + 544 p.

Worster, Donald. Under Western Skies: Nature and History in the American West. New York: Oxford University Press, 1992. 292 p.

Information about the article

This article was created with the support of the program for the development of scientific journals under state contract No. 14.597.11.0035 concluded between the Ministry of Education and Science of the Russian Federation and NEICON

Author: Sen', Dmitriy Vladimirovich — Dr. Sc. in History, Professor, Institute of History and International Relations, Southern Federal University, Rostov-on-Don, Russia, Leading Researcher, Kalmyk Scientific Centre, Russian Academy of Sciences, Elista, Russia, e-mail: dsen1974@mail.ru, OrcID 0000-0002-5222-4685; Scopus ID 57211031437

Title: Frontier research in present-day Russia: Shaky boundaries of the academic dialogue

Summary: The article analyses contemporary Russian scholars' usage of the frontier concept in studies devoted to borders, borderlands, contact zones, and the history of Russian development of new lands. The author highlights controversial areas in such studies, including the features of frontier territories, the typology of Russian frontiers, and the search for counterparts to the term "frontier" in the Russian language and among Russian historical and geographical names. Cases discussed include Russian scholars deny the heuristic potential of the frontier concept for Russian history. Both the rhetoric of 
such authors and their sometimes far-from-scholarly system of arguments are analyzed. The author considers problems and perspectives of frontier theory in comparison with a similar situation in Ukrainian and American historiography. The modern efforts of scholars from different countries to study lexical analogues of the concept of "frontiers" in order to explain the historical and cultural local specifics of various territories were analyzed. At the same time, some explorers are offering to refuse of this concept in research practices. Attention is drawn to reasons why this theory is especially actively used by representatives of various regional academic centers in Russia. The common and distinctive features of studies in the history of various Russian frontiers are characterized. The most prominent among those frontiers are the Siberian and the southern (North Caucasian) frontiers. The article points out the connection between some development trends of frontier investigations in Russia and the interest growth to regional history, the history of the Russian state expansion and the borders formation of foreign policy. The author draws attention to a new generation of studies which has developed under the influence of the frontier theory. They have significantly transformed the state of academic humanitarian community of the South of Russia, a community that is quiet conservative in relation to modern scientific concepts. Finally, perspective topics were proposed for further use of the frontier concept in research on the history of Russia.

Keywords: discussion, classification, Russian historiography, comparative studies, contact zones, borders, frontier, frontier theory

\section{References:}

Alekseev, Veniamin Vasilyevich; Alekseeva, Elena Veniaminovna; Zubkov, Konstantin Ivanovich; Poberezhnikov, Igor Vasilyevich. Aziatskaya Rossiya v geopoliticheskoy i tsivilizatsionnoy dinamike. $X V I-X X$ veka [Asian Russia in geopolitical and civilizational dynamics. $16^{\text {th }}-20^{\text {th }}$ centuries]. Moscow: Nauka Publ., 2004. 600 p. (in Russian).

Barret, Thomas. M. At the Edge of Empire. The Terek Cossacks and the North Caucasus Frontier, 1700-1860. Boulder, CO: Westview Press, 1999. XV + 243p.

Barret, Thomas M. Linii neopredelennosti: Severokavkazskiy «frontir» Rossii [The Line of Uncertainty: Russia's North Caucasian «Frontier»], in David-Fox, Michael (ed.). Amerikanskaya rusistika: Vekhi istoriografi poslednikh let. Imperatorskiy period: Antologiya [American-Russian Studies: Milestones in Historiography of Recent Years. Imperial period: Anthology]. Samara: Samara University Press, 2000. Pp. 163-193. (in Russian).

Basalaeva, Irina Petrovna. Kriterii frontira: K postanovke problemy [Criteria for the Frontier: To the Formulation of the Problem], in Teoriya i praktika obshchestvennogo razvitiya. 2012. No. 2. Pp. 46-49. (in Russian).

Bassin, Mark. Turner, Solovyev, and the «Frontier Hypothesis»: The Nationalist Signification of Open Spaces, in The Journal of Modern History. 1993. Vol. 65. No. 3 (Sept.). Pp. 473-511.

Berberova, Elena Georgievna. Osobennosti severokavkazskogo frontira Rossiyskoy imperii (1722-1864 gg.): Avtoref. dis. ... kand. ist. nauk [Features of the North Caucasian frontier of the Russian Empire (1722-1864): Thesis for a PhD in History degree]. Vladikavkaz, 2014. 22 p. (in Russian).

Boeck, Brian James. Frontir ili pograniche? Rol' zybkikh granits v istorii donskogo kazachestva [Frontier or borderland? The role of shaky boundaries in the history of the Don Cossacks], in Sotsial'naya organizatsiya $i$ obychnoe pravo: materialy nauch. konf. [Social organization and customary law]. Krasnodar: Freemen Masters Publ., 2001. Pp. 147-155. (in Russian).

Chernous, Viktor Vladimirovich. Kul'turno-tsivilizatsionnoe vzaimodeystvie na Severnom Kavkaze: Istoriya i nekotorye sovremennye tendentsii [Cultural and civilizational interaction in the North Caucasus: History and some current trends], in Istoriya: Nauchnye poiski i problemy. Rostov-on-Don: North Caucasian Scientific Center of Higher Education Publ., 2000. Pp. 164-187. (in Russian).

Chornovol, Igor. Vidpovidniki ponyattya frontier u inshikh movakh [Concepts of frontier in other languages], in Koko, Eugeniusz; Nowak, Magdalena; Zaszkilniak, Leonid (eds). Historia-Mentalność-Tożsamość. Rosja i Europa Zachodnia w polskiej i ukraińskiej historiografii XIX i XX wieku [History-mentality-identity. Russia and Western Europe in the Polish and Ukrainian historiography of the $19^{\text {th }}$ and $20^{\text {th }}$ centuries]. Gdańsk: Wydawnictwo Uniwersytetu Gdańskiego, 2013. Pp. 125-140. (in Ukrainian).

Etkind, Aleksandr Markovich. Vnutrennyaya kolonizatsiya. Imperskiy opyt Rossii [Internal Colonization. Russia's Imperial Experience]. Transl. by V. Makarov. Moscow: New Literary Review Publ., 2013. 448 p. (in Russian). 
Gatagova, Lyudmila Sultanovna. Kontaktnye zony v istorii Vostochnoy Evropy [Contact areas in the history of Eastern Europe]. Moscow, 1998. 182 p. (in Russian).

Gerasimov, Ilya Vladimirovich; Glebov, Sergey Vladimirovich; Kaplunovskiy, Aleksandr Petrovich; Mogilner, Marina Borisovna; Semenov, Aleksandr Mikhaylovich. V poiskakh novoy imperskoy istorii [In search of a new imperial history], in Novaya imperskaya istoriya postsovetskogo prostranstva [New imperial history of the post-Soviet space]. Kazan': Tsentr issledovaniy natsionalizma i imperii Publ., 2004. Pp. 7-29. (in Russian). Gerasimov, Ilya Vladimirovich; Glebov, Sergey Vladimirovich; Kusber, Yan; Mogilner, Marina Borisovna; Semenov, Aleksandr Mikhaylovich. Novaya imperskaya istoriya i vyzovy imperii [New Imperial history and the challenges of Empire], in Ab Imperio. 2010. No. 1. Pp. 19-51. (in Russian).

Gerasimov, Ilya Vladimirovich (ed.). Novaya imperskaya istoriya Severnoy Evrazii. Chast' 1: Konkuriruyushchie proekty samoorganizatsii: VII-XVII vv. [A New Imperial History of Northern Eurasia. Part 1: Competing projects of self-organization: 7th-17th centuries]. Kazan': «Ab Imperio» Publ., 2017. 364 p. (in Russian).

Golovanova, Svetlana Aleksandrovna; Shnayder, Vladimir Gennadyevich. Kontseptsiya «frontira»v sovremennoy kavkazovedcheskoy literature [A concept of «frontier» in the Caucasus modern literature], in Vestnik Adygeyskogo gosudarstvennogo universiteta. Ser. 1: Regionovedenie: Filosofiya, istoriya, sotsiologiya, yurisprudentsiya, politologiya, kul'turologiya. 2012. Issue 3. Pp. 66-74. (URL: https://cyberleninka.ru/ article/n/kontseptsiya-frontira-v-sovremennoy-kavkazovedcheskoy-literature (last visited - August, 20, 2018)). (in Russian).

Granitsy imperii: V poiskakh predelov primenimosti istoricheskikh metanarrativov. Ot redaktsii [The borders of the empire: In search of the limits of applicability of historical metanarratives: From the editors], in Ab imperio. 2003. No. 1. Pp. 9-23. (in Russian).

Gribovskiy, Vladislav Vladimirovich. Kazachestvo i ego svyaz's tyurkskim mirom v istoriografii pozdney Rossiyskoy imperii, SSSR i postsovetskogo prostranstva [Cossacks and its relationship with the Turkic world in the historiography of the late Russian Empire, the USSR and the post-Soviet space], in Gribovskiy, Vladislav Vladimirovich; Trepavlov, Vadim Vintserovich (eds). Kazachestvo v tyurkskom i slavyanskom mirakh [Cossacks in the Turkic and Slavic worlds]. Kazan': Institute of Archaeology named after A. Kh. Khalikov (Tatarstan Academy of Sciences) Press, 2018. Pp. 11-69. (in Russian).

Hall, Thomas D. Puzzles in the Comparative Study of Frontiers: Problems, Some Solutions, and Methodological Implications, in Journal of World-Systems Research. 2009. Vol. XV. № 1. Pp. 25-47.

Hämäläinen, Pekka; Truett, Samuel. On Borderlands, in The Journal of American History. 2011. Vol. 98. No. 2 (September). Pp. 338-361.

Kappeler, Andreas. Yuzhniy i vostochniy frontir Rossii v XVI-XVIII vekakh [The Southern and Eastern Frontier of Russia in the $16^{\text {th }}-18^{\text {th }}$ Centuries], in Ab Imperio. 2003. No. 1. Pp. 47-64. (in Russian).

Khlynina, Tatyana Pavlovna; Krinko, Evgeniy Fedorovich; Urushadze, Amiran Tarielovich. Rossiyskiy Severniy Kavkaz: Istoricheskiy opyt upravleniya i formirovaniya granits regiona [Russian North Caucasus: historical experience in managing and shaping the region's borders]. Rostov-on-Don: The Southern Scientific Centre (RAS) Press, 2012. 272 p. (in Russian).

Khodarkovsky, Michael. Russia's Steppe Frontier: The Making of a Colonial Empire, 1500-1800. Bloomington; Indianapolis: Indiana University Press, 2002. 304 p.

Khromykh, Aleksandr Stanislavovich. K voprosu o primenenii ponyatiy «kolonizatsiya» $\mathrm{i}$ «frontir» v izuchenii istorii Sibiri [To the issue of the application of the concepts of «colonization» and «frontier» in the studying of the history of Siberia], in Istoricheskie issledovaniya v Sibiri: Problemy i perspektivy. 2009. Pp. 108-113. (in Russian).

Kopytoff, Igor. The African Frontier: The Reproduction of Traditional African Societies. Bloomington: Indiana University Press, 1987. 288 p.

Kravchenko, Volodimir. Kharkov / Kharkiv: Stolitsa pogranichya [Kharkov/Kharkiv: The capital of the borderlands]. Vilnius: European Humanities University Press, 2010. 357 p. (in Russian).

Limerick, Patricia Nelson. The Legacy of Conquest. The unbroken past of the American West. New York: W. W. Norton Publ., 1987. 396 p.

Limerick, Patricia Nelson. What on Earth is the New Western History?, in Limerick, Patricia Nelson; Milner II, Clyde A.; Rankin, Charles E. Kansas (eds). Trails: Toward a new western history. Lawrence: University of Kansas Press, 1991. Pp. 81-88. 
Matveev, Oleg Vladimirovich. Ot fronta $k$ frontiru: Istoriko-antropologicheskie ocherki [From front to frontier: Historical and anthropological essays]. Krasnodar: Edvi Publ., 2015. 272 p. (in Russian).

Miller, Aleksey Ilyich. Imperiya Romanovykh i natsionalizm: Esse po metodologii istoricheskogo issledovaniya [Romanov Empire and nationalism: Essay on the methodology of historical research]. Moscow: New Literary Review Publ., 2006. 248 p. (in Russian).

Miller, Aleksey Ilyich. Mental'nye karty istorika i svyazannye s etim opasnosti [The mental maps of the historian. And the associated dangers], in Istoricheskiye zapiski. Moscow, 2002. Issue 5 (123). Pp. 323-333. (in Russian).

Mizis, Yuriy Aleksandrovich; Skobelkin, Oleg Vladimirovich; Papkov, Andrey Igorevich. Russkiy frontir: Politicheskie, sotsial'nye i ekonomicheskie aspekty. (Yug Rossii v XVI - konets XVIII v.) [Russian frontier: Political, social and economic aspects. (South of Russia in the $16^{\text {th }}$ - the end of the $18^{\text {th }}$ century)], in Vestnik Tambovskogo gosudarstvennogo universiteta. 2015. Vol. 20. Issue 10. Pp. 7-15. (in Russian).

Nash, Gerald D. Creating the West: Historical Interpretations 1890-1990. Albuquerque: University of New Mexico Press, 1991. 318 p.

Oleynikov, Dmitriy Ivanovich. Chelovek na razlome kul'tur: Osobennosti psikhologii russkogo ofitseragortsa v period Bolshoy Kavkazskoy voyny [Man at the break of cultures: Features of the psychology of the Russian officer-mountaineer during the Great Caucasian War], in Zvezda. 2001. No. 8. Pp. 95-99 (in Russian).

Oleynikov, Dmitriy Ivanovich. Teoriya kontaktnykh zon i dialoga kul'tur primenitel'no k prodvizheniyu Rossii na Severniy Kavkaz v 1810-1860-e gg. [The theory of contact zones and the dialogue of cultures as applied to the advancement of Russia to the North Caucasus in the 1810-1860s], in Actio nova. Moscow: Globus Publ., 2000. Pp. 315-337. (in Russian).

Panarina, Darya Sergeevna. Granitsa i frontir kak faktor razvitiya regiona i/ili strany [Border and frontier as a factor in the development of a region and/or country], in Istoriya i sovremennost'. 2015. No. 1 (March). Pp. 15-41. (in Russian).

Power, Daniel; Standen, Naomi. (Eds.). Frontiers in Question. Eurasian Borderlands. 700-1700. New York: St. Martin's Press, 1999. 293 p.

Priymak, Yuriy Vladimirovich. Severo-Vostochnoe Prichernomorye vo vnutri- $i$ vneshnepoliticheskikh protsessakh formirovaniya yuzhnykh granits Rossii (konets XVII-pervaya tret XIX v.) [The northeastern Black Sea coast in the domestic and foreign policy processes of the formation of the southern borders of Russia (late $17^{\text {th }}$ - first third of the 19 $9^{\text {th }}$ century]. Armavir: Poliprint Publ., 2011. 359 p. (in Russian).

Repina, Lorina. Mezhdu lokal'nym i global'nym: Poiski integrativnykh podkhodov [Between the local and the global: In search for integrative approaches], in Regionalna istoriya Ukraini: Zbirnik naukovikh statey. Kyiv: Institute of History of Ukraine (NASU) Press, 2011. Issue 5. Pp. 9-28. (in Russian).

Riber, Alfred. Menyayushchiesya kontseptsii i konstruktsii frontira: Sravnitel'no-istoricheskiy podkhod [Changing concepts and constructions of frontiers: A comparative historical approach], in Novaya imperskaya istoriya postsovetskogo prostranstva: Sbornik statey. Kazan': Center for the Studies of Nationalism and Empire Publ., 2004. Pp. 199-222. (in Russian).

Rose, Deborah Bird; Davis, Richard (eds). Dislocating the Frontier: Essaying the mystique of the Outback. Canberra: ANU E Press, 2005. 206 p.

Severnyi Kavkaz v sostave Rossiiskoi imperii [North Caucasus as part of the Russian Empire]. Moscow: Novoe literaturnoe obozrenie Publ., 2007. 460 p. (in Russian).

Shebzukhova, Tatyana Aleksandrovna; Berberova, Elena Georgievna. Severokavkazskiy frontir Rossiyskoy imperii (1722-1864) [North Caucasian frontier of the Russian Empire (1722-1864)]. Moscow: OOO «TsIUMiNL» Publ., 2015. 224 p. (in Russian).

Slotkin, Richard. Gunfighter nation: The myth of the frontier in twentieth-century America. Norman: University of Oklahoma Press, 1998. 864 p.

Slotkin, Richard. Regeneration through violence: The mythology of the American frontier, 1600-1860. Norman: University of Oklahoma Press, 2000. 670 p.

Slotkin, Richard. The fatal environment: The myth of the frontier in the age industrialization, 1800-1890. Norman: University of Oklahoma Press, 1998. 636 p.

Soboleva, Tatyana Nikolayevna; Bobrov, Denis Sergeevich. Sovremennaya rossiyskaya istoriografiya kontseptsii frontira [Modern Russian historiography of the concept of a frontier], in Izvestiya Altayskogo gosudarstvennogo universiteta. 2011. No. 4-1. Pp. 189-193. (in Russian). 
Sunderland, Willard. Taming the wild field: Colonization and Empire on the Russian Steppe. Ithaca; London: Cornell University Press, 2004. XVII + 239 p.

Urushadze, Amiran Tarielovich. Rossiyskiy Severnyy Kavkaz: Istoricheskiy opyt upravleniya i formirovaniya granits regiona [Russian North Caucasus: Historical experience of governance and formation of region borders]. Rostov-on-Don: South Federal University Press, 2012.

Vinogradov, Boris Vitalyevich; Klochkov, Oleg Borisovich. «Severokavkazskiy frontir» ot fonda Sorosa: $\mathrm{K}$ voprosu o tselyakh i kharaktere istoricheskoy mistifikatsii [«North Caucasian Frontier» from the Soros Foundation: On the issue of the goals and nature of historical mystification], in Istoricheskoye regionovedeniye Severnogo Kavkaza - vuzu i shkole. [Historical Regional Studies of the North Caucasus - to the university and school]. Moscow; Armavir: Armavir State Pedagogical Institute Press, 2008. Pp. 29-33. (in Russian). White, Richard. Middle Ground: Indians, Empire, and Republics in the Great Lakes Region. 1650-1815. New York: Cambridge University Press, 1991. XVI + 544 p.

Worster, Donald. Under Western Skies: Nature and History in the American West. New York: Oxford University Press, 1992. 292 p.

Zamyatin, Dmitriy Nikolaevich. Russkie v Tsentral'noy Azii vo vtoroy polovine XIX veka: Strategii reprezentatsii i interpretatsii istoriko-geograficheskikh obrazov granits [Russians in Central Asia in the second half of the $19^{\text {th }}$ century: Strategies for the representation and interpretation of historical and geographical images of the borders], in Vostok. Afro-aziatskie obshchestva: istoriya i sovremennost'. Moscow, 2002. No. 1. Pp. 43-64. (in Russian).

Zamyatina, Nadezhda Yuryevna. Zona osvoeniya (frontir) i ee obraz v amerikanskoy i russkoy kul'turakh [The zone of development (frontier) and its image in American and Russian cultures], in Obshchestvennye nauki i sovremennost'. 1998. No. 2. Pp. 75-88. (in Russian). 